\title{
Studies on the variation in germination and seedling growth of Abies pindrow Spach. (Royle) in Garhwal region of Uttarakhand, India
}

\author{
Haseeb UI Rashid Masoodi ${ }^{1 *}$, Manisha Thapliyal ${ }^{1}$ and V. R. R Singh ${ }^{2}$ \\ ${ }^{1}$ Silviculture Division, Forest Research Institute, Dehradun, Uttarakhand-248006, INDIA \\ ${ }^{2}$ Additional PCCF (M\&E), HPSFD, Solan (H.P.), INDIA \\ *Corresponding author. E-mail: haseebgis@gmail.com
}

Received: August 12, 2014; Revised received: October 5, 2014; Accepted: November 28, 2014

\begin{abstract}
Abies pindrow species is facing a problem of natural regeneration and the absence of adequate regeneration in Indian fir forests has drawn the attention of forest officers, researchers and scientists for a long time. The present study was undertaken in the state of Uttarakhand where four sites bearing $A$. pindrow forests were selected. The study was conducted to compare the seeds of the four sites to draw relevant conclusions. Two sites Mundali and Deoban fall under Chakrata forest division and Bhukki and Dharali sites fall under Uttarkashi forest division. The aim of the study was to determine variation in germination of seeds of $A$. pindrow collected from four locations in the state of Uttarakhand. A significant variation was observed in seed germination (germination percent, mean germination time, peak value, germination energy, germination value, germination speed) and seed growth parameters (seed length, seed width and seed thickness). The seed source of Dharali site was found as the best source followed by Deoban in comparison to other two sites. Dharali site showed highest germination percentage (25\%), highest germination value (2.664) and highest germination energy (25.00) from its seed source, thereby concluding to be the best seed source site. The viable and healthy seed source can be considered to be most fruitful in propagation and regeneration techniques.
\end{abstract}

Keywords: Abies pindrow, Germination percent, Germination time, Germination speed, Germination value

\section{INTRODUCTION}

Abies pindrow, commonly known as fir, silver fir, low level fir or tosh, belonging to family Pinaceae, is a tall evergreen tree with dense conical crown, which frequently extend to almost ground level. Talking specifically of North-West Himalayan states of Himachal Pradesh, Jammu and Kashmir and Uttarakhand, these occupy about $31.15 \%$ of area under coniferous forests and amount for $48.8 \%$ of the total growing stock in these states (Singh and Singh, 1984). Pure fir is rear, usually associated with scattered trees of Picea smithiana, Cedrus deodara, Pinus wallichiana, Quercus dilatata, Q. semecarpifolia and Taxus baccata (Singh and Singh, 1987a). The natural regeneration of silver fir, is generally poor and first attention to this problem was paid by Redcliffe (1906). Since then, the problem of natural regeneration of these species has been constantly engaging the attention of the forest scientists.

Germination of a seed is the initial, and under some circumstances, critical step in afforestation by natural or artificial means. Seeds of different species and of the same species from different provenances behave differently in their germination response and knowledge of same is very essential for understanding plantations programmes. Similarly a species may be found in a wide variety of climatic regions, but the germination behaviour may differ according to provenance.

Germinability is a measure of the ability of population of seeds to germinate or the maximum percentage of seeds that will germinate under favourable conditions (Bewley and Black, 1978). Variation in seed germination is due to a complex of environmental and genetic factors during seed formation and subsequent handling of treatments (Wang et al., 1982).

Depending on the species, germination responses of seed vary according to geographical and environmental factors, viz. latitude, elevation, soil moisture, soil nutrient, temperature, kind and density of plant cover, degree of habitat disturbance of the site where the seed matures. The objective of the present investigation was to understand the nature, extent and pattern of variation existing in seeds at different sites of $A$. pindrow forests in respect to germination and seedling growth and to draw conclusions in order to combat with the problem of natural regeneration the species is facing over a period of time. Such an investigation may help in developing conservation strategies in the laboratory and nursery conditions. Keeping above in view the present study was conducted to study the variation in germination and seedling growth of Abies pindrow Spach. (Royle) in Garhwal region of Uttarakhand. 


\section{MATERIALS AND METHODS}

Four sites bearing Abies pindrow forests in the state of Uttarakhand were selected for undertaking the present study. Two sites Mundali and Deoban fall under Chakrata forest division and Bhukki and Dharali sites fall under Uttarkashi forest division. The altitudinal range of all the four sites varied between 2650-4200 m above msl. The latitudinal and longitudinal ranges of all the four sites have been given in Table 1. The various attributes of seed germination and seedling growth were studied. From every seed source, a composite sample of seed was drawn by mixing the seed collected from selected trees for seed studies. Observations were recorded in respect of the following seed parameters.

Seed length, width and thickness ( $\mathbf{m m})$ : Seeds were randomly drawn from the seed pool in order to determine their size and shape. For each individual seed, three principal dimensions: length $\mathrm{L}$, width $\mathrm{W}$, and thickness $\mathrm{T}$, all in $\mathrm{mm}$, were measured using a digital caliper.

Germination percent: The germination test was carried out by placing the seeds on moist filter paper in petri plates at $25^{\circ} \mathrm{C}$. Four replicates of 100 seeds each were used for the test. Germination percent was recorded by the formula:

Germination percent $=$ Seed germinated $/$ Total seed sown X 100

Germination value: Germination value $(\mathrm{GV})$ is the index combined speed and completeness of seed germination. Daily germination counts were recorded and calculated as per the method given by Czabator (1962).

$\mathrm{GV}=\mathrm{PV} \times \mathrm{MDG}$

Where, $\mathrm{PV}=$ Peak value of germination, $\mathrm{MDG}=$ Mean daily germination

Mean germination time (MGT): It is an expression of total germination at the end of test period with time taken to complete germination.

MGT $=\Sigma$ (Daily germination*days $) /$ No. of seeds sown.

Germination energy: Germination energy (GE) was calculated on the basis of percentage of total number of seed that had germinated when germination reached its peak.

$\mathrm{GE}=$ Number of seed germinated upto the time of peak germination / total number of seed sown X 100

Peak value: Peak value was calculated as the maximum mean daily germination (MDG) reached at any time during the period of test (Czabator, 1962)

Statistical analysis: Data was subjected to analysis of variance and covariance using SPSS programme and excel. Two way ANOVA was used to determine interaction between sites and years on germination indices and seedling growth parameters.

\section{RESULTS}

The latitudinal and longitudinal ranges for each of the four sites have been shown in Table 1. Variation in germination percentage, germination energy and germination value $(\mathrm{GV})$ of seeds grown in laboratory was found significant among different seed sources of the given four sites with germination percentage of 25, 21, 14 and 14 for Dharali, Deoban, Bhukki and Mundali respectively for the year 2012. The values showed an increased trend in the next year i.e 2013 with germination percentage values of 29, 24, 18 and 17 for Dharali, Deoban, Bhukki and Mundali respectively. Highest mean germination time was recorded for Bhukki site (10.729) while minimum for Deoban site (9.033) for the year 2012. Whereas in the year 2013, highest mean germination time was recorded for Bhukki site (11.300) while minimum for Deoban site (9.289). Highest germination value was seen for Dharali site (1.910) while minimum for Bhukki site (0.645) in 2012. Highest germination value was seen for Dharali site (2.664) while minimum for Bhukki site (0.929) in 2013. Highest germination energy was shown by Dharali site (25.00) and minimum value (14.00) by Bhukki and Mundali sites in the year 2012. Whereas in the year 2013, highest germination energy was shown by Dharali site (29.00) and minimum by Mundali site (17.00). (table 2).

Maximum seed length $(12.23 \mathrm{~mm})$ was recorded in Dharali site while minimum $(9.658 \mathrm{~mm})$ in Bhukki site and maximum seed width of $6.827 \mathrm{~mm}$ was observed for Dharali site and minimum seed width of $5.335 \mathrm{~mm}$ was shown by Bhukki site whereas maximum seed thickness was shown by Deoban site $(2.896 \mathrm{~mm})$ while minimum seed thickness of $2.609 \mathrm{~mm}$ in Mundali site in the year 2012. For the year 2013, maximum seed length $(11.992 \mathrm{~mm})$ was recorded in Dharali site while minimum $(9.32 \mathrm{~mm})$ in Bhukki site. Maximum seed width of $6.658 \mathrm{~mm}$ was observed for Dharali site and minimum seed width of $4.847 \mathrm{~mm}$ was shown by Bhukki site whereas maximum seed thickness was seen for Dharali site $(2.827 \mathrm{~mm})$ while minimum seed thickness of $2.468 \mathrm{~mm}$ in Bhukki site (Table 3).

Table 1. Geographic information of the study sites of A. pindrow forests.

\begin{tabular}{lccc}
\hline Forest Divisions & Sites & Latitudinal Range (N) & Longitudinal Range (E) \\
\hline \multirow{2}{*}{ Chakrata } & Mundali & $30^{\circ} 48^{\prime} 40.6^{\prime \prime}-30^{\circ} 49^{\prime} 02.6^{\prime \prime}$ & $77^{\circ} 55^{\prime} 39.9^{\prime \prime}-77^{\circ} 57^{\prime} 01.9^{\prime \prime}$ \\
& Deoban & $30^{\circ} 44^{\prime} 42.0^{\prime \prime}-30^{\circ} 45^{\prime} 28.3^{\prime \prime}$ & $77^{\circ} 51^{\prime} 38.7^{\prime \prime}-77^{\circ} 52^{\prime} 29.5^{\prime \prime}$ \\
\multirow{2}{*}{ Uttarkashi } & Bhukki & $30^{\circ} 46^{\prime} 46.79^{\prime \prime}-30^{\circ} 54^{\prime} 03.55^{\prime \prime}$ & $78^{\circ} 39^{\prime} 55.14^{\prime \prime}-78^{\circ} 45^{\prime} 02.59^{\prime \prime}$ \\
& Dharali & $30^{\circ} 00^{\prime} 13.28^{\prime \prime}-30^{\circ} 00^{\prime} 49.1^{\prime \prime}$ & $78^{\circ} 45^{\prime} 43.3^{\prime \prime}-78^{\circ} 46^{\prime} 56.5^{\prime \prime}$ \\
\hline
\end{tabular}


Table 2. Multiple comparisons of various germination attributes for year and site.

\begin{tabular}{lccccccc}
\hline Year & Site & $\begin{array}{c}\text { Germination } \\
(\boldsymbol{\%})\end{array}$ & $\begin{array}{c}\text { MGT } \\
(\text { Days) }\end{array}$ & $\begin{array}{c}\text { Peak } \\
\text { value }\end{array}$ & $\begin{array}{c}\text { Germination } \\
\text { value }\end{array}$ & $\begin{array}{c}\text { Germination } \\
\text { energy }\end{array}$ & $\begin{array}{c}\text { Germination } \\
\text { speed }\end{array}$ \\
\hline \multirow{2}{*}{2012} & Mundali & $14.00^{\mathrm{a}}$ & $10.15^{\mathrm{b}}$ & $1.24^{\mathrm{a}}$ & $0.66^{\mathrm{a}}$ & $14.00^{\mathrm{a}}$ & $0.35^{\mathrm{a}}$ \\
& Deoban & $21.00^{\mathrm{bc}}$ & $9.03^{\mathrm{a}}$ & $2.00^{\mathrm{b}}$ & $1.56^{\mathrm{b}}$ & $21.00^{\mathrm{bc}}$ & $0.59^{\mathrm{b}}$ \\
& Bhukki & $14.00^{\mathrm{a}}$ & $10.73^{\mathrm{bc}}$ & $1.22^{\mathrm{a}}$ & $0.65^{\mathrm{a}}$ & $14.00^{\mathrm{a}}$ & $0.33^{\mathrm{a}}$ \\
& Dharali & $25.00^{\mathrm{cd}}$ & $10.29^{\mathrm{b}}$ & $2.05^{\mathrm{b}}$ & $1.91^{\mathrm{b}}$ & $25.00^{\mathrm{cd}}$ & $0.62^{\mathrm{bc}}$ \\
& Mundali & $17.00^{\mathrm{ab}}$ & $10.13^{\mathrm{b}}$ & $1.47^{\mathrm{a}}$ & $0.95^{\mathrm{a}}$ & $17.00^{\mathrm{ab}}$ & $0.42^{\mathrm{a}}$ \\
\multirow{2}{*}{2013} & Deoban & $24.00^{\mathrm{c}}$ & $9.29^{\mathrm{a}}$ & $2.21^{\mathrm{bc}}$ & $2.00^{\mathrm{b}}$ & $24.00^{\mathrm{c}}$ & $0.66^{\mathrm{bc}}$ \\
& Bhukki & $18.00^{\mathrm{ab}}$ & $11.30^{\mathrm{c}}$ & $1.38^{\mathrm{a}}$ & $0.93^{\mathrm{a}}$ & $18.00^{\mathrm{ab}}$ & $0.40^{\mathrm{a}}$ \\
& Dharali & $29.00^{\mathrm{d}}$ & $10.12^{\mathrm{b}}$ & $2.46^{\mathrm{c}}$ & $2.66^{\mathrm{c}}$ & $29.00^{\mathrm{d}}$ & $0.72^{\mathrm{c}}$ \\
\hline SED & & 1.41 & 0.26 & 0.12 & 0.19 & 1.41 & 0.04 \\
P-value & 2.00 & 0.37 & 0.18 & 0.27 & 2.00 & 0.05 \\
LSD & & 0.97 & 0.51 & 0.76 & 0.56 & 0.97 & 0.95 \\
\hline
\end{tabular}

Same letter in the column are not significantly different $\mathrm{P}=0.05$

\section{DISCUSSION}

Results showed that Dharali site showed best germination of seeds and showed direct correlation with seed size and weight. Similar results have been described by Dunlop and Barnett, 1983, Rokaya and Münzbergová (2012), who concluded that the seed size and weight have pronounced effects on seed germination. Generally, large seeds have fast and uniform germination, due to more endosperm nutrient pool (Kandya, 1978). Therefore, seed source variation in germination percent and related traits may be ascribed to the significant differences, observed in seed dimensions and weight. Germination values varied considerably among seed sources and exhibited a random pattern, which is an index of combining speed and completeness of germination and itself is a function of seed size and weight (Czabator, 1962) and (Dunlop and Barnett, 1983). Seed germination and seedling growth parameters showed considerable variation for the different sites. Highest germination energy was seen in Dharali site and it has been concluded that germination energy is a measure of speed of germination, it gives an idea of the vigour of the seed and of the seedling, which it produces (Willan, 1985). The interest in germination energy is based on the theory that only those seeds which germinate rapidly and vigorously under favourable conditions are likely to be capable of producing vigorous seedling in field conditions, whereas weak or

Table 3. Multiple comparisons of various seed growth parameters for the year and site.

\begin{tabular}{|c|c|c|c|c|}
\hline Year & Site & Seed length $(\mathrm{mm})$ & Seed width (mm) & Seed thickness (mm) \\
\hline \multirow{4}{*}{2012} & Dharali & $12.23^{\mathrm{c}}$ & $6.83^{c}$ & $2.89^{c}$ \\
\hline & Deoban & $11.35^{\mathrm{b}}$ & $6.37^{\mathrm{bc}}$ & $2.90^{\mathrm{c}}$ \\
\hline & Mundali & $10.08^{\mathrm{a}}$ & $6.18^{b}$ & $2.61^{\mathrm{ab}}$ \\
\hline & Bhukki & $9.66^{\mathrm{a}}$ & $5.34^{\mathrm{a}}$ & $2.73^{b}$ \\
\hline \multirow{4}{*}{2013} & Dharali & $11.99^{\mathrm{bc}}$ & $6.66^{\mathrm{c}}$ & $2.83^{\mathrm{b}}$ \\
\hline & Deoban & $11.39^{\mathrm{b}}$ & $6.07^{\mathrm{b}}$ & $2.75^{\mathrm{b}}$ \\
\hline & Mundali & $9.53^{\mathrm{a}}$ & $5.97^{\mathrm{b}}$ & $2.48^{\mathrm{a}}$ \\
\hline & Bhukki & $9.32^{\mathrm{a}}$ & $4.85^{\mathrm{b}}$ & $2.47^{\mathrm{a}}$ \\
\hline SEM & & 0.26 & 0.16 & 0.08 \\
\hline SED & & 0.37 & 0.23 & 0.11 \\
\hline P-value & & 0.72 & 0.76 & 0.68 \\
\hline LSD & & 0.73 & 0.45 & 0.22 \\
\hline
\end{tabular}

Same letter in the column are not significantly different $\mathrm{P}=0.05$ 
delayed germination is often fatal Result of the present study strongly supports this hypothesis as seed sources having higher seed germination also had better seed growth.

It has been observed that most of the forests are irregular seed producers with long cycles of good seed years such 10 years in $A$. pindrow. Due to this reason large quantity of high quality seed needs to be collected and stored in good seed years for use in intervening years to ensure a continuous supply of seed for sustained annual production of nursery stock to meet exigency of afforestation programmes. Therefore, storage of seeds is of paramount importance to preserve the seeds from collection to the time of sowing and to make available for the years when little or no seed has been produced (Holmes and Buszewicz, 1958). Variation in seed germination is due to a complex of environmental and genetic factors during seed formation and subsequent handling of treatments (Wang et al., 1982). Some seed sources showed better performance in certain locations than the other and the use of seed of a provenance in such areas having very many different climatic and edaphic conditions, often results in poor performance or failure (Read, 1971; Rowe and Chiang, 1973).

Germination value is a further expression of germination energy and has been used as an integrated measure of seed quality in Acacia nilotica (Ginwal and Gera, 2000) and Terminalia ivorensis (Okoro, 1976).

Mahendru (1936) concluded that coniferous seed had the poorest germination capacity (about 25\%). With the poor soil conditions resulting in unhealthy growth and entrance of black heart fungi, it is likely that by the time it reaches the soil, it becomes unless for germination. Glover (1936) recognized that reproductive of both silver fir and spruce appears plentifully and that an adequate mixture of broad leaved trees and bushes has a most favourable effect on the natural regeneration of fir and spruce. It had been observed in Mundali forests of Chakrata Division that even artificial plantation of spruce fails in certain natural spruce areas as they have been treated badly in the past. Further it can be concluded that the reproductive system of conifers is exclusively sexual and the natural regeneration, in turn, depends on the production, dispersal and germination capacity of seeds and successful establishment of seedlings. Seed germination of most temperate coniferous species is inhibited by evolved trait seed dormancy (West et al., 1970; Leadem, 1986).

\section{Conclusion}

It can be concluded from the present investigation that there were comparable differences existing in seeds at different sites of $A$. pindrow forests in respect to germination and seedling growth. Such an investigation may help in developing conservation strategies in the laboratory and nursery conditions with seeds which are found to be the best in order to promote successful regeneration of such species.

\section{ACKNOWLEDGEMENTS}

The first author is thankful to the officials of Forest department, Uttarakahand for their kind support and help during extensive survey.

\section{REFERENCES}

Bewley, J.D. and Black, M. (1978). The Physiology and Biochemistry of Seeds, Berlin, pringer-Verlag, V. 1, pp 306.

Czabator, F.J. (1962). Germination value: an index combining speed and completeness of pine seed germination. Forest Sciences, 8(4): 386-396.

Dunlap, J.R. and Barnett, J.P. (1983). Influence of seed size on germination and early development of loblolly pine (Pinus taeda L.) germinants. Canadian Journal of Forest Research, 13: 40-44.

Ginwal, H.S. and M. Gera. (2000). Genetic variation in seed germination and growth performance of 12 Acacia nilotica provenances in India. Journal of Tropical Forest Science, 12(2): 286-297.

Glover, H.M. (1936). The practical problem of the management of the Himalayan fir forests. Indian Forester, 62 (5): 276-282.

Holmes, G.D, Buszewicz, G. (1958). The storage of seed of temperate forest tree species. For. Abstracts, 19:455-475.

Kandya, A.K. (1978). Relationship among seed weight and various growth factors in Pinus oocarpa seedlings. Indian Forester, 104(8): 561-567.

Leadem, C.L. (1986). Stratification of Abies amabilis seeds. Can. J. For. Res., 16: 755-760.

Mehendru, I.D. (1936). The problem of natural regeneration of silver fir (Abies spectabilis), Indian Forester, 62(1): 260-275.

Okoro, O.O. (1976). Germination of Terminalia ivqrensis seeds source under various conditions of germination. In 'Seed problem' Proceedings second international symposium on physiology of seed germination. October 1976, IUFRO, Fiji, Japan.

Read, R.A. (1971). Scots pine in eastern Nebreska: A provenance study. US For. Serv. Res. Pap., Rocky Mt. Forest Range Exp. Sta. No. RM-78, pp.13.

Redcliffe, E. (1906). Researches on the regeneration of silver fir. Indian Forester, 32: 402-404.

Rokaya, M.B. and Münzbergová, Z. (2012). Effect of light, temperature and seed mass on germination of two species of the Himalayan rhubarb. Journal of Medicinal Plants Research, 6(37): 5032-5037.

Rowe, K.E. and Chiang, K.K. (1973). Provenances of fir in pacific northwest region. II. Field performances age nine. Silvae Genetica, 22(4): 115-119.

Singh, J.S. and Singh, S.P. (1987a). Forest vegetation of Himalaya. Botanical Review 53(3): 81-92.

Singh, V. and Singh, R.V. (1984). Silvicultural, dispersal, seed germination and seedling establishment in natural forest of silver fir and spruce. Indian Forester, 110(6): 529-539.

Wang, B.S.P., Pitel, A. and Webb, D.P. (1982). Environmental and genetic factors affecting tree and shrub seeds. In: Advances in Research and Technology of Seeds. (Ed. J.R. Thomson). Part 7, Centre for 
Agriculture Publishing and Documentation, Wageningen, Netherlands, pp. 87-135.

West, W.C., Frattarelli, F.J. and Russin, K.J. (1970). Effect of stratification and gibberellin on seed germination in
Ginkgo biloba. Bull. Torrey. Bot. Club, 97: 380-384.

Willan, R.L. (1985): A guide to forest seed handling with particular reference to the topics. FAO Forestry paper 20/2. 